\title{
Performance Evaluation of Fe-Al Bimetallic Particles for the Removal of Potentially Toxic Elements from Combined Acid Mine Drainage-Effluents from Refractory Gold Ore Processing
}

\author{
Elham Aghaei ${ }^{1}$, Zexiang Wang ${ }^{1}$, Bogale Tadesse ${ }^{1}\left(\mathbb{D}\right.$, Carlito Baltazar Tabelin ${ }^{2} \oplus$, Zakaria Quadir ${ }^{3}$ \\ and Richard Diaz Alorro $1, * \mathbb{D}$ \\ 1 Western Australian School of Mines: Minerals, Energy and Chemical Engineering, Faculty of Science and \\ Engineering, Curtin University, Kalgoorlie, WA 6403, Australia; elham.aghaei@postgrad.curtin.edu.au (E.A.); \\ zexiang.wang@postgrad.curtin.edu.au (Z.W.); bogale.tadesse@curtin.edu.au (B.T.) \\ 2 School of Minerals and Energy Resources Engineering, Faculty of Engineering, University of New South \\ Wales, Sydney, NSW 2052, Australia; c.tabelin@unsw.edu.au \\ 3 John de Laeter Centre and School of Civil and Mechanical Engineering, Faculty of Science and Engineering, \\ Curtin University, Bentley, WA 6845, Australia; zakaria.quadir@curtin.edu.au \\ * Correspondence: Richard.Alorro@curtin.edu.au; Tel.: +61-890886187
}

\section{check for}

updates

Citation: Aghaei, E.; Wang, Z.; Tadesse, B.; Tabelin, C.B.; Quadir, Z.; Alorro, R.D. Performance Evaluation of Fe-Al Bimetallic Particles for the Removal of Potentially Toxic

Elements from Combined Acid Mine Drainage-Effluents from Refractory Gold Ore Processing. Minerals 2021 11, 590. https://doi.org/10.3390/ $\min 11060590$

Academic Editor: Juan Antelo

Received: 19 April 2021

Accepted: 27 May 2021

Published: 31 May 2021

Publisher's Note: MDPI stays neutral with regard to jurisdictional claims in published maps and institutional affiliations.

Copyright: (c) 2021 by the authors Licensee MDPI, Basel, Switzerland. This article is an open access article distributed under the terms and conditions of the Creative Commons Attribution (CC BY) license (https:// creativecommons.org/licenses/by/ $4.0 /)$

\begin{abstract}
Acid mine drainage (AMD) is a serious environmental issue associated with mining due to its acidic $\mathrm{pH}$ and potentially toxic elements (PTE) content. This study investigated the performance of the Fe-Al bimetallic particles for the treatment of combined AMD-gold processing effluents. Batch experiments were conducted in order to eliminate potentially toxic elements (including $\mathrm{Hg}$, $\mathrm{As}$, $\mathrm{Cu}, \mathrm{Pb}, \mathrm{Ni}, \mathrm{Zn}$, and $\mathrm{Mn}$ ) from a simulated waste solution at various bimetal dosages (5, 10, and $20 \mathrm{~g} / \mathrm{L}$ ) and time intervals ( 0 to $90 \mathrm{~min}$ ). The findings show that metal ions with greater electrode potentials than $\mathrm{Fe}$ and $\mathrm{Al}$ have higher affinities for electrons released from the bimetal. Therefore, a high removal (>95\%) was obtained for $\mathrm{Hg}$, As, $\mathrm{Cu}$, and $\mathrm{Pb}$ using $20 \mathrm{~g} / \mathrm{L}$ bimetal in $90 \mathrm{~min}$. Higher uptakes of $\mathrm{Hg}, \mathrm{As}, \mathrm{Cu}$, and $\mathrm{Pb}$ than $\mathrm{Ni}, \mathrm{Zn}$, and $\mathrm{Mn}$ also suggest that electrochemical reduction and adsorption by Fe-Al (oxy) hydroxides as the primary and secondary removal mechanisms, respectively. The total $\mathrm{Al}^{3+}$ dissolution in the experiments with a higher bimetal content (10 and $20 \mathrm{~g} / \mathrm{L}$ ) were insignificant, while a high release of Fe ions was recorded for various bimetal dosages. Although the secondary Fe pollution can be considered as a drawback of using the Fe-Al bimetal, this issue can be tackled by a simple neutralization and Fe precipitation process. A rapid increase in the solution $\mathrm{pH}$ (initial $\mathrm{pH} 2$ to $>5$ in $90 \mathrm{~min}$ ) was also observed, which means that bimetallic particles can act as a neutralizing agent in AMD treatment system and promote the precipitation of the dissolved metals. The presence of chloride ions in the system may cause akaganeite formation, which has shown a high removal capacity for PTE. Moreover, nitrate ions may affect the process by competing for the released electrons from the bimetal owing to their higher electrode potential than the metals. Finally, the Fe-Al bimetallic material showed promising results for AMD remediation by electrochemical reduction of PTE content, as well as acid-neutralization/metal precipitation.
\end{abstract}

Keywords: acid mine drainage; gold processing effluents; Fe-Al bimetallic particles; electrochemical reduction

\section{Introduction}

Acid mine drainage (AMD) refers to acidic runoff rich in high concentrations of metal ions, such as iron $(\mathrm{Fe})$, manganese $(\mathrm{Mn})$, zinc $(\mathrm{Zn})$, copper $(\mathrm{Cu})$, lead $(\mathrm{Pb})$, nickel $(\mathrm{Ni})$, arsenic (As), cadmium (Cd), aluminum (Al), and mercury ( $\mathrm{Hg})$ [1-3]. AMD is associated with mining and mineral processing activities and comes from the natural oxidation of sulfide-bearing minerals (such as pyrite) exposed to water, oxygen, and microbes $[4,5]$. AMD is considered one of the most prevalent causes of environmental pollution which stems from its high acidity $(\mathrm{pH}<3)$ and toxic metal content [6]. Tailings waste from 
processing of refractory gold ores is one of the major areas of concern as it contains sulfide species and is very likely to produce AMD over time, especially in dry climates and high evaporation rates [7]. Therefore, parts of tailings with sulfide minerals content exposed to air will start to oxidize during summer to form AMD.

To tackle the issue of AMD, many attempts have been made to limit the generation and release of AMD by protecting sulfide minerals from air, water, and bacteria and minimizing their interactions [5,8-13]. However, due to practical constraints involved in the prevention strategy [14], the next available option is AMD treatment by either active or passive methods [2]. The most common active methods include neutralization using caustic soda (sodium hydroxide), calcium hydroxide $\left(\mathrm{Ca}(\mathrm{OH})_{2}\right)$ or limestone $\left(\mathrm{CaCO}_{3}\right)$, as well as adsorption, ion exchange, and crystallization $[6,15]$. However, the interest in improving the efficiency of AMD remediation techniques motivated researchers to develop passive methods, which involves biological and chemical treatment of AMD using wetlands [16], permeable reactive barriers $[17,18]$, compost reactors, and bioreactors, and cost-effective materials such as recycled concrete aggregates [14], sulfur-reducing bacteria (SRB) [19], and fly ash [20]. Studies with AMD have focused on neutralizing the acidity and heavy metal removal. However, in the case of combined AMD-waste effluents resulting from refractory gold processing with $\mathrm{Cl}^{-}$and $\mathrm{NO}_{3}$ content, it has not been considered anywhere before.

When exploring the most appropriate treatment techniques, it is crucial to consider the use of non-toxic, cost-effective, and high-performance materials with the lowermost potential of hazardous wastes/bi-products generation. Accordingly, zero-valent iron (ZVI) has been considered a promising element for removal of heavy metals and PTE from the aquatic environment [21] and the most common reactive material used in permeable reactive barriers (PRBs) for remediating AMD and contaminated groundwater [22]. Depending on the environmental conditions ( $\mathrm{pH}$, redox, and oxic-anoxic conditions), type and concentration of dissolved constituents; ZVI can remove heavy metals and PTE from solutions effectively through adsorption, surface complexation, reductive precipitation, and co-precipitation $[3,22]$. However, one major drawback with this kind of application is the decreasing reactivity and performance of ZVI in the long-term due to iron corrosion and surface passivation by an iron oxy-hydroxide film [21,22]. Recently, iron-based bimetallic materials have been developed aimed at improving the reactivity and efficiency of ZVI in removing PTE. In this regard, due to the synergistic effect of Fe and Al, the Fe-Al bimetal has shown remarkably improved reductive ability for the contaminants [23]. The potential difference between $\mathrm{Fe}$ and $\mathrm{Al}\left(\mathrm{E}^{0}\left(\mathrm{Al}^{3+} / \mathrm{Al}^{0}\right)=-1.667 \mathrm{~V}\right.$ and $\left.\mathrm{E}^{0}\left(\mathrm{Fe}^{2+} / \mathrm{Fe}^{0}\right)=-0.44 \mathrm{~V}\right)$ promotes better electron transfer within the bimetallic system and slows the passivation of the Fe surface, resulting in a higher reducing capacity for target contaminants [24].

A number of studies have examined the performance of $\mathrm{Fe}-\mathrm{Al}$ bimetallic particles for their ability to remove heavy metals, including Cr(VI) [25], As(III) [26], U(VI) [27] from waste solutions. Their findings demonstrated the high capacity, selectivity, and rapid removal rate of target metal ions by the bimetal, predominantly through electrochemical reduction. Moreover, in a study by Han et al. (2016) [28], a higher removal efficiency for aqueous heavy metal ions (Cr(VI), Cd(II), Ni(II), Cu(II), and $\mathrm{Zn}(\mathrm{II})$ ) was achieved by acid-washed ZVAl/ZVI mixture in PRBs compared to acid-washed ZVAl or ZVI alone. One significant finding to emerge from this previous study was that the Fe-Al bimetal formation during the reaction has been identified as a major contributing factor to the high removal efficiency. Despite previous studies describing Fe-Al bimetal as a potential technique in wastewater remediation, the direct application of this bimetal in AMD treatment has not been reported to date. According to standard electrode potential of $\mathrm{Fe}, \mathrm{Al}$ and metals found in AMD such as $\mathrm{Pb}, \mathrm{Cu}, \mathrm{Hg}$, and $\mathrm{Zn}$, it is clear that the Fe-Al bimetallic material is an effective medium for treating AMD. Compared to common passive treatment methods, which suffer from long processing time [29], Fe-Al bimetallic particles are fast and effective for metal removal. Moreover, both $\mathrm{Al}$ and Fe are among the most abundant elements on the earth, and the amount of required bimetal for AMD remediation, and waste generated, is very small. Therefore, this paper evaluates the performance of the Fe-Al bimetal for acid- 
neutralization and removal of potentially toxic elements from simulated AMD combined with gold processing effluents by considering the influencing parameters including bimetal dosage and reaction time.

\section{Materials and Methods}

\subsection{Preparation of Combined AMD-Waste Effluent from Refractory Gold Processing}

The combined AMD prepared in this study represents the combination of AMD and effluents resulting from the processing of refractory gold ores containing sulfide minerals in the Goldfields region of Western Australia. Parts of tailings from these processing plants, exposed to atmospheric conditions, are very liable to generate AMD over time. The gold processing tailings dam contains $\mathrm{Cl}^{-}$, and $\mathrm{NO}_{3}{ }^{-}$ions because of using hydrochloric acid $(\mathrm{HCl})$ or nitric acid $\left(\mathrm{HNO}_{3}\right)$ in the acid washing stage [30] and lead nitrate in cyanidation [31,32]. Moreover, scaling up the mining and processing operations has risen the demand for groundwater sources. The available source of process water in Australia, especially in arid regions, is hypersaline groundwater with high $\mathrm{Cl}^{-}$content $[33,34]$. With regard to what mentioned above, the combined AMD solution was prepared using $1000 \mathrm{mg} / \mathrm{L}$ single-element standard solutions of $\mathrm{Mn}, \mathrm{Pb}, \mathrm{As}, \mathrm{Ni}, \mathrm{Cu}, \mathrm{Zn}$, and $\mathrm{Hg}$ in $2 \%$ nitric acid (Sigma-Aldrich), as well as calcium chloride $\left(\mathrm{CaCl}_{2}\right)$, sodium chloride $(\mathrm{NaCl})$ and ferrous sulfate $\left(\mathrm{FeSO}_{4}\right)$. The initial $\mathrm{pH}$ of the prepared solution was adjusted to 2 using sodium hydroxide $(\mathrm{NaOH})$. The synthetic AMD was with initial metal concentrations shown in Table 1.

Table 1. Initial solute concentrations (mg/L) in the synthetic AMD-gold processing effluents.

\begin{tabular}{cccccccccccc}
\hline $\mathbf{H g}$ & $\mathrm{Al}$ & $\mathrm{Ca}$ & $\mathrm{Mn}$ & $\mathrm{Na}$ & $\mathrm{Fe}$ & $\mathrm{As}$ & $\mathrm{Pb}$ & $\mathrm{SO}_{4}{ }^{2-}$ & $\mathrm{Ni}$ & $\mathrm{Cu}$ & $\mathrm{Zn}$ \\
\hline 32.5 & 1.4 & 273.6 & 36.3 & $10,896.0$ & 388.4 & 9.3 & 91.4 & 652.0 & 18.2 & 53.4 & 31.9 \\
\hline
\end{tabular}

\subsection{Synthesis of Fe-Al Bimetallic Particles}

All the reagents used in this study were of analytical grade. The Fe-Al bimetallic particles were synthesized using ZVAl powder $(\mathrm{D} 90=86.5 \mu \mathrm{m})$ obtained from Barnes (NSW, Australia), and ferric chloride $\left(\mathrm{FeCl}_{3} \cdot 6 \mathrm{H}_{2} \mathrm{O},>99 \%\right.$ purity) purchased from Chemsupply (SA, Australia). Fe-Al bimetals were prepared by optimizing the procedure used by Chen et al. (2008) [24] and Fu et al. (2015) [25], which are based on the electrochemical reduction and deposition of iron on the ZVAl surface. The first step was to remove the unreactive layer of aluminum oxide from ZVAl using acid washing, in which $20 \mathrm{~mL}$ of $1 \mathrm{M}$ hydrochloric acid $(\mathrm{HCl})$ was added to flasks containing $3 \mathrm{gr} \mathrm{ZVAl}$ in a shaking incubator and agitated for $15 \mathrm{~min}$ at $40{ }^{\circ} \mathrm{C}$ and $110 \mathrm{rpm}$. This treatment was followed by the cementation step by adding $30 \mathrm{~mL} \mathrm{Fe}^{3+}$ solutions with a certain concentration (to give $0.5 \mathrm{~g}$ Fe to $1 \mathrm{gr} \mathrm{Al}$ ) to the flasks and agitating for $30 \mathrm{~min}$. Then, the Fe/ Al particles were recovered and rinsed with deionized water, and dried in a vacuum desiccator. The residual Fe and $\mathrm{Al}$ concentrations in the solution was measured (data not shown) to calculate the total Fe and $\mathrm{Al}$ content of recovered bimetallic particles in each preparation batch as $1 \mathrm{~g}$ $\mathrm{Fe} / 2.1 \mathrm{~g} \mathrm{Al}$ ( \pm 0.05 for 3 samples) (Equations (1) and (2)).

$$
\begin{aligned}
& \mathrm{Fe}_{\mathrm{T}}=\mathrm{Fe}_{0}-\mathrm{Fe}_{\mathrm{r}} \\
& \mathrm{Al}_{\mathrm{T}}=\mathrm{Al}_{0}-\mathrm{Al}_{\mathrm{r}}
\end{aligned}
$$

where

$\mathrm{Fe}_{\mathrm{T}}$ and $\mathrm{Al}_{\mathrm{T}}$ are the total $\mathrm{Fe}$ and $\mathrm{Al}$ content of the bimetal, $\mathrm{Fe}_{0}$ and $\mathrm{Al}_{0}$ are applied $\mathrm{Fe}$ and $\mathrm{Al}$ content, and $\mathrm{Fe}_{\mathrm{r}}$ and $\mathrm{Al}_{\mathrm{r}}$ are residual $\mathrm{Fe}$ and $\mathrm{Al}$ ions concentrations. 


\subsection{Analytical Techniques}

The concentration of dissolved ions were analyzed using inductively coupled plasma optical emission spectroscopy (ICP-OES) and mass spectroscopy (ICP-MS). X-ray powder diffraction (XRD) of bimetallic particles was performed using an Olympus diffractometer (Olympus Scientific Solutions Americas, USA) with Co-K $\alpha$ radiation source in the range between 5 and $55^{\circ}(2 \theta)$. To characterize the size distribution of ZVAl powder and bimetallic particles, Mastersizer Malvern 3000 was used (Malvern Instruments Ltd., Malvern, UK). The structure and elemental mapping of the bimetal were determined using a Tescan Clara field emission scanning electron microscope (SEM) equipped with an energy dispersive spectrometer (EDS) manufactured by the Oxford Instrument, Oxfordshire, UK).

\subsection{Experimental Procedure}

To investigate the combined AMD treatment using Fe-Al bimetallic particles, batch experiments were conducted in an incubator shaker at $110 \mathrm{rpm}$ and $25^{\circ} \mathrm{C}$ with varying time intervals from 10 to $90 \mathrm{~min}$. In each batch, a specific amount of $\mathrm{Fe}-\mathrm{Al}$ bimetals $(5,10$, and $20 \mathrm{~g} / \mathrm{L})$ was added to Erlenmeyer flasks containing $25 \mathrm{~mL}$ of the prepared waste solution. No acid or alkali was subsequently added to control the $\mathrm{pH}$ during the reaction. All experiments were conducted in duplicate, and average values were presented. After a specified time, the solution content of each flask was recovered by filtration and analyzed for heavy metal concentrations. The percentage of heavy metal removal (\% R) was calculated using Equation (3):

$$
\% \mathrm{R}=\frac{\mathrm{C}_{0}-\mathrm{C}}{\mathrm{C}_{0}} \times 100
$$

where $\mathrm{C}_{0}$ : Initial heavy metal ion concentration, $\mathrm{mg} / \mathrm{L}$, and C: Residual heavy metal ion concentration, $\mathrm{mg} / \mathrm{L}$.

Stabilities of pollutants were modelled by the Geochemist's Workbench ${ }^{\circledR}$ [35] with the THERMODDEM database [36] based on measured solute activities in the experiments.

\section{Results and Discussion}

\subsection{Characterization of the Fe-Al Bimetallic Particles}

The particle size distribution of the ZVAl and the synthesized Fe-Al bimetallic material is illustrated in Figure 1. The graph shows that there was an increase in the particle size of the Fe-Al bimetal compared to ZVAl. Ninety percent of the ZVAl distribution has a smaller particle size of $86.5 \mu \mathrm{m}\left(\mathrm{D}_{90}\right)$ while this value increased to $134 \mu \mathrm{m}$ after acid washing and loading with $\mathrm{Fe}$. Moreover, the diffraction peaks at $45.0^{\circ}$ for both $\mathrm{Al}$ and $\mathrm{Fe}$ and $52.5^{\circ}$ for Fe in the XRD pattern (Figure 2) confirmed the presence of both $\mathrm{Al}$ and $\mathrm{Fe}$ in the bimetal structure.

In addition, the core-shell structure of the bimetal has been detected in the SEM mapping (Figure 3). From the EDS spectra shown in Figure 3, it can be seen that $\mathrm{Al}$ is mostly found in the core while Fe is the dominant element on the surface of Al.

\section{2. $p H$ Monitoring}

The $\mathrm{pH}$ plays a vital role in the AMD treatment as increasing in $\mathrm{pH}$ can lead to the dissolved metal and hydroxides precipitation [37]. Figure 4 shows the experimental data for the solution $\mathrm{pH}$ at a different time and bimetal dosage. As illustrated in the graph, a clear trend of increasing $\mathrm{pH}$ with time from 0 to $30 \mathrm{~min}$ for all bimetal dosage at initial $\mathrm{pH} 2$ was observed. However, from 30 to $90 \mathrm{~min}$, a slight change in the $\mathrm{pH}$ was recorded. In addition, for the combined AMD treated with the greater bimetal dosages, the higher $\mathrm{pH}$ values were obtained. The $\mathrm{pH}$ of the solution containing $20 \mathrm{~g} / \mathrm{L}$ of bimetal reached more than 5.5 after $30 \mathrm{~min}$, although it exhibited a slight decrease from 60 to $90 \mathrm{~min}$. The Eh of the solutions was $0.5 \mathrm{~V}$ at initial $\mathrm{pH}$ of 2 just before adding the bimetal and decreased to minimum value of around $0.21 \mathrm{~V}$ in $90 \mathrm{~min}$ for all bimetal dosages. 


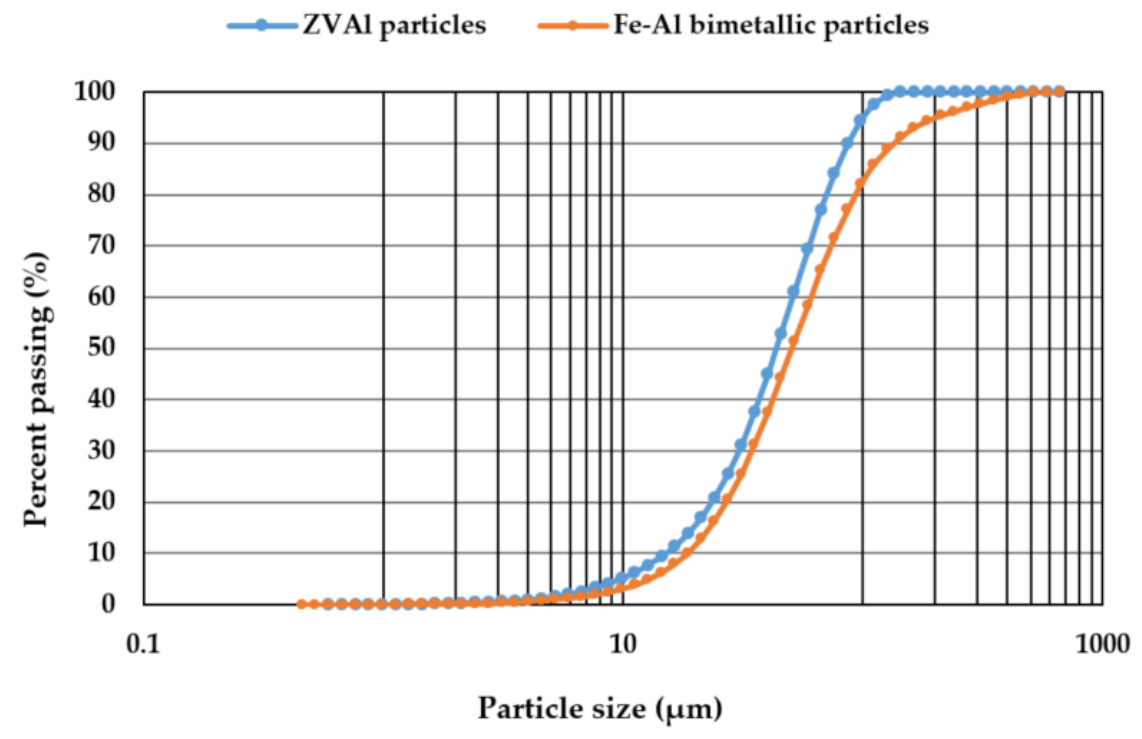

Figure 1. Cumulative particle size distribution of ZVAl and Fe-Al bimetallic material.

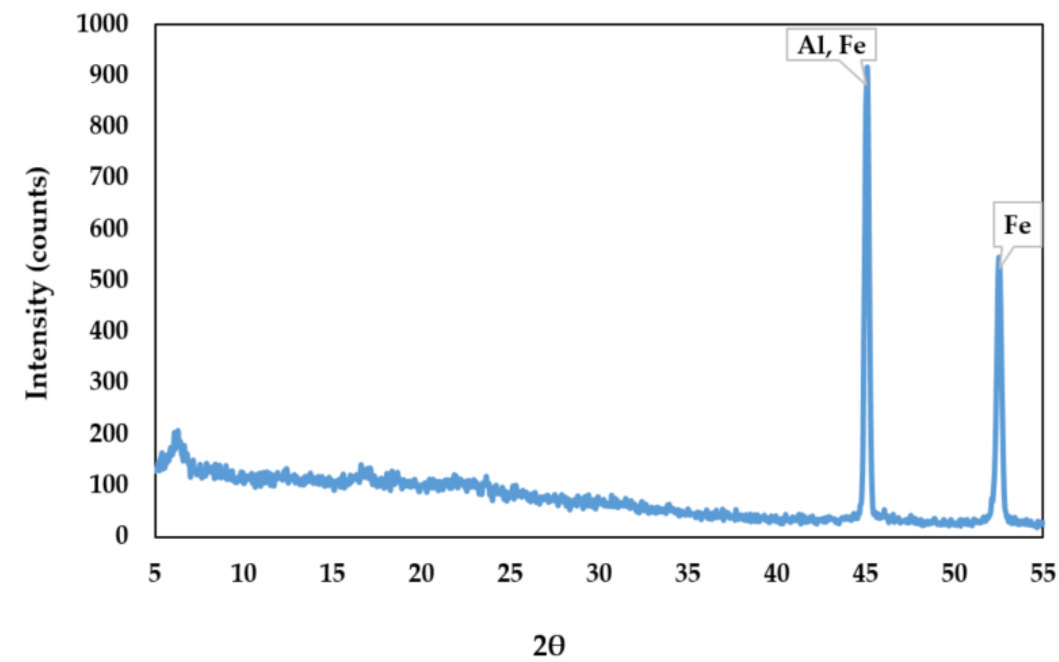

Figure 2. XRD pattern for the synthesized Fe-Al bimetal.

In the acidic aqueous system containing $\mathrm{Fe}-\mathrm{Al}$ bimetallic particles and dissolved oxygen, the oxidation of $\mathrm{ZVAl}$ to $\mathrm{Al}^{3+}\left(\mathrm{E}^{0}\left(\mathrm{Al}^{3+} / \mathrm{Al}^{0}\right)=-1.667 \mathrm{~V}\right)$ and $\mathrm{ZVI}$ to $\mathrm{Fe}^{2+}\left(\mathrm{E}^{0}\left(\mathrm{Fe}^{2+} / \mathrm{Fe}^{0}\right)=-0.44 \mathrm{~V}\right)$ (Equations (4) and (5)) was accompanied by oxygen reduction in the presence of protons $\left(\mathrm{H}^{+}\right)$and the generation of hydrogen peroxide $\left(\mathrm{H}_{2} \mathrm{O}_{2}\right)\left(\mathrm{E}^{0}\left(\mathrm{O}_{2} / \mathrm{H}_{2} \mathrm{O}_{2}\right)=+0.695 \mathrm{~V}\right)$ [38] (Equations (6) and (7)) [38,39]. Hydrogen peroxide subsequently accelerated the ZVAl corrosion to $\mathrm{Al}^{3+}$ (Equation (8)) $[40,41]$ and triggered a Fenton reaction, where $\mathrm{Fe}^{2+}$ and $\mathrm{H}_{2} \mathrm{O}_{2}$ reacted to form $\mathrm{Fe}^{3+}$, hydroxyl radicals $\left(\mathrm{OH}^{-}\right)$, and hydroxyl ions $\left(\mathrm{OH}^{-}\right)$(Equation (9)) [38]. In addition, more $\mathrm{OH}^{-}$released into the solution, where $\mathrm{H}_{2} \mathrm{O}$ in the solution picked up electrons. The evolution of $\mathrm{H}_{2}$ gas resulted from $\mathrm{H}_{2} \mathrm{O} / \mathrm{H}^{+}$reduction in the solution was also evident in the experiments (Equations (10) and (11)). To sum up, increasing the solution $\mathrm{pH}$ is obviously related to the release of $\mathrm{OH}^{-}$ions into the solution via several reactions in the solution, as discussed above.

$$
\begin{gathered}
\mathrm{Al}^{0} \rightarrow \mathrm{Al}^{3+}+3 \mathrm{e}^{-} \\
\mathrm{Fe}^{0} \rightarrow \mathrm{Fe}^{2+}+2 \mathrm{e}^{-} \\
\mathrm{O}_{2}+\mathrm{H}^{+}+\mathrm{e}^{-} \rightarrow \mathrm{HO}_{2}
\end{gathered}
$$




$$
\begin{gathered}
2 \mathrm{HO}_{2} \rightarrow \mathrm{H}_{2} \mathrm{O}_{2}+\mathrm{O}_{2} \\
\mathrm{Al}^{0}+3 \mathrm{H}_{2} \mathrm{O}_{2} \rightarrow \mathrm{Al}^{3+}+3 \mathrm{OH}+\mathrm{OH}^{-} \\
\mathrm{Fe}^{2+}+\mathrm{H}_{2} \mathrm{O}_{2} \rightarrow \mathrm{Fe}^{3+}+\mathrm{OH}+\mathrm{OH}^{-} \\
2 \mathrm{H}_{2} \mathrm{O}+2 \mathrm{e}^{-} \rightarrow \mathrm{H}_{2}+2 \mathrm{OH}^{-} \\
2 \mathrm{H}^{+}+2 \mathrm{e}^{-} \rightarrow \mathrm{H}_{2}
\end{gathered}
$$
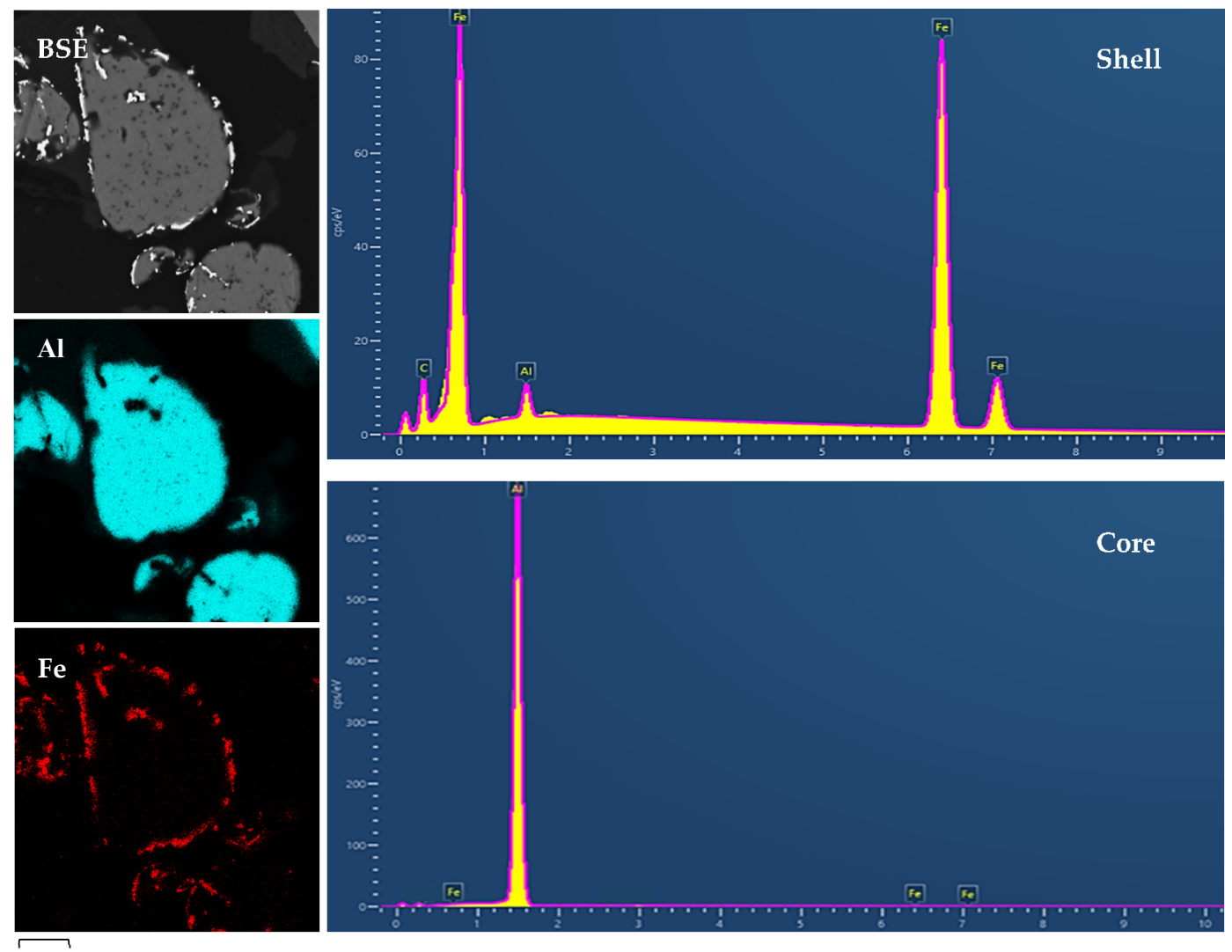

${ }_{25 \mathrm{sm}}$

Figure 3. SEM image and EDS spectra of Fe-Al bimetallic material with a core-shell structure.

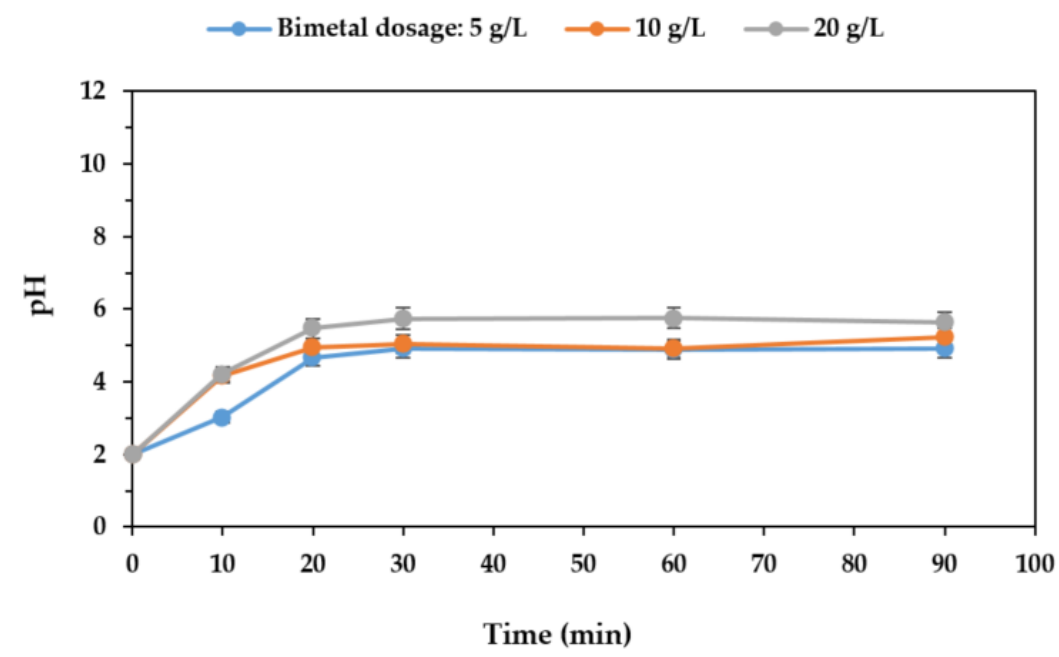

Figure 4. Variation in the $\mathrm{pH}$ of the combined AMD solution treated by the Fe-Al bimetal at a different time and bimetal dosage. 


\subsection{Metal Removal by the Fe-Al Bimetallic Material}

The percent removal of various metals from the synthetic combined AMD treated by the Fe-Al bimetallic material for 90 min was compared and illustrated in Figure 5 . What stands out in this figure is the higher uptake of $\mathrm{Hg}, \mathrm{As}, \mathrm{Cu}$ and $\mathrm{Pb}$ at all bimetal levels compared with $\mathrm{Zn}, \mathrm{Ni}$, and $\mathrm{Mn}$. Experiments with $20 \mathrm{~g} / \mathrm{L}$ of the bimetal resulted in significant removal of $\mathrm{Hg}(99.74 \%)$, $\mathrm{As}(99.80 \%), \mathrm{Cu}(98.20 \%)$, and $\mathrm{Pb}(95.50 \%)$, while it dropped to $69.50 \%$ removal for $\mathrm{Zn}, 22.34 \%$ for $\mathrm{Ni}$, and $<5 \%$ for $\mathrm{Mn}$. As previously stated, the higher standard redox potential of the aqueous contaminants than the $\mathrm{Al}$ and $\mathrm{Fe}$ is the underlying cause of a greater removal rate. Table 2 displays the standard reduction potential of various aqueous species in the experiments at $25^{\circ} \mathrm{C}$. The data are arranged in the increasing order of $\mathrm{E}^{0}$, which means an increase in the tendency of species to get reduced. Therefore, under competitive conditions in the process, the loss of $\mathrm{Hg}$, $\mathrm{As}, \mathrm{Cu}$, and $\mathrm{Pb}$ was higher than $\mathrm{Ni}, \mathrm{Zn}$, and $\mathrm{Mn}$, as they have a greater attraction for electrons released from the bimetal.

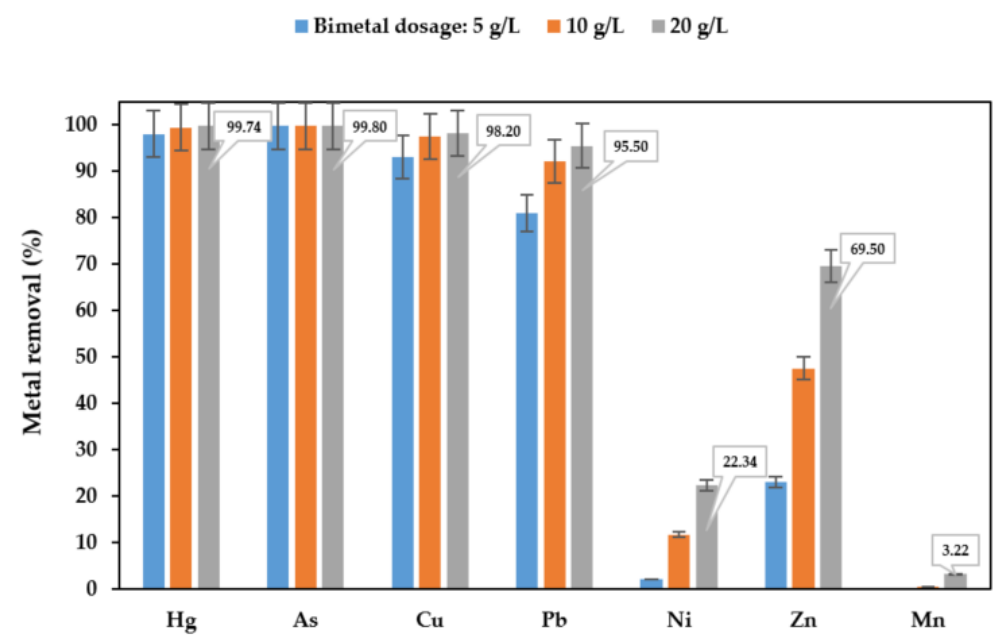

Figure 5. A comparison of the removal of various PTE from the synthetic combined AMD by Fe-Al bimetallic particles after $90 \mathrm{~min}$ and initial $\mathrm{pH} 2$.

Table 2. Standard reduction potential of different species in aqueous solution at $25^{\circ} \mathrm{C}[24,42]$.

\begin{tabular}{cll}
\hline Aqueous Species & \multicolumn{1}{c}{ Reduction Half Reactions } & $\mathbf{E}^{\mathbf{0}}(\mathbf{V})$ \\
\hline Aluminum $(\mathrm{Al})$ & $\mathrm{Al}^{3+}+3 \mathrm{e}^{-} \rightarrow \mathrm{Al}_{(\mathrm{S})}$ & -1.68 \\
Manganese $(\mathrm{Mn})$ & $\mathrm{Mn}^{2+}+2 \mathrm{e}^{-} \rightarrow \mathrm{Mn}_{(\mathrm{S})}$ & -1.18 \\
Zinc $(\mathrm{Zn})$ & $\mathrm{Zn}^{2+}+2 \mathrm{e}^{-} \rightarrow \mathrm{Zn}_{(\mathrm{S})}$ & -0.76 \\
Iron (Fe(II)) & $\mathrm{Fe}^{2+}+2 \mathrm{e}^{-} \rightarrow \mathrm{Fe}_{(\mathrm{S})}$ & -0.44 \\
Nickel (Ni) & $\mathrm{Ni}^{2+}+2 \mathrm{e}^{-} \rightarrow \mathrm{Ni}_{(\mathrm{S})}$ & -0.28 \\
Lead (Pb) & $\mathrm{Pb}^{2+}+2 \mathrm{e}^{-} \rightarrow \mathrm{Pb}_{(\mathrm{S})}$ & -0.13 \\
Copper $(\mathrm{Cu}(\mathrm{I}))$ & $\mathrm{Cu}^{2+}+\mathrm{e}^{-} \rightarrow \mathrm{Cu}^{+}$ & +0.15 \\
Arsenic $(\mathrm{As}(\mathrm{III}))$ & $\mathrm{H}_{3} \mathrm{AsO}_{3}+3 \mathrm{H}^{+}+3 \mathrm{e}^{-} \rightarrow \mathrm{As}+3 \mathrm{H}_{2} \mathrm{O}$ & +0.24 \\
Copper $(\mathrm{Cu}(\mathrm{II}))$ & $\mathrm{Cu}^{2+}+2 \mathrm{e}^{-} \rightarrow \mathrm{Cu}_{(\mathrm{S})}$ & +0.34 \\
Arsenic $(\mathrm{As}(\mathrm{V}))$ & $\mathrm{H}_{3} \mathrm{AsO}_{4}+2 \mathrm{H}^{+}+2 \mathrm{e}^{-} \rightarrow \mathrm{HAsO}_{2}+4 \mathrm{H}_{2} \mathrm{O}$ & +0.56 \\
Iron (Fe(III)) & $\mathrm{Fe}^{3+}+\mathrm{e}^{-} \rightarrow \mathrm{Fe}^{2+}$ & +0.77 \\
Mercury $(\mathrm{Hg})$ & $\mathrm{Hg}^{2+}+2 \mathrm{e}^{-} \rightarrow \mathrm{Hg}_{(\mathrm{l})}$ & +0.86 \\
\hline
\end{tabular}

The variation of residual metal concentrations over time at different bimetal dosages $(5,10$, and $20 \mathrm{~g} / \mathrm{L})$ and initial $\mathrm{pH}$ of 2 are shown in Figure 6. The initial $\mathrm{Hg}$ concentration in the solution (Figure 6a) dropped significantly in $10 \mathrm{~min}$ at all bimetal dosages, although the residual $\mathrm{Hg}(\mathrm{II})$ was slightly higher in the experiments with $5 \mathrm{~g} / \mathrm{L}$ bimetal $(2.14 \mathrm{mg} / \mathrm{L})$ compared to 10 and $20 \mathrm{~g} / \mathrm{L}(<0.2 \mathrm{mg} / \mathrm{L})$. In addition, ZVAl and ZVI on the bimetal surface, $\mathrm{Fe}^{2+}$ ions $\left(\mathrm{E}^{\circ}\left(\mathrm{Fe}^{3+} / \mathrm{Fe}^{2+}\right)=+0.77\right)$ have also been considered as a reducing agent for $\mathrm{Hg}(\mathrm{II})$ 
elimination from the solution [43]. Moreover, the increase in the solution $\mathrm{pH}$ to $>4.5$ in $20 \mathrm{~min}$ at various bimetal dosages, resulted in the precipitation of Fe (oxy)hydroxides on the bimetal surface (Figure 7a), which can sequester $\mathrm{Hg}$ (II) from the solution [43].

A similar trend to $\mathrm{Hg}$ was observed for the residual $\mathrm{As}$ and $\mathrm{Cu}$ concentrations (Figure $6 \mathrm{~b}, \mathrm{c}$ ) within $90 \mathrm{~min}$ of AMD treatment using the bimetal. Despite that within 20 min of the process using $5 \mathrm{~g} / \mathrm{L}$ bimetal As uptake was lower than that of 10, and $20 \mathrm{~g} / \mathrm{L}$, the removal rate was almost the same from 20 to $90 \mathrm{~min}$. In addition, the initial $\mathrm{Cu}$ concentration of $53.44 \mathrm{mg} / \mathrm{L}$ went down to $3.5,1.4$, and $1 \mathrm{mg} / \mathrm{L}$ at $90 \mathrm{~min}$ for 5,10 , and $20 \mathrm{~g} / \mathrm{L}$ bimetal, respectively. The higher bimetal concentrations performed more effectively for the $\mathrm{Pb}$ (II) reduction, so that the best result was obtained by using $20 \mathrm{~g} / \mathrm{L}$ of the bimetal at 60 min (96\% removal) (Figure 6d).

Prior studies $[26,44]$ have reported the possible mechanisms for As removal by the Fe-Al bimetal as follows: (1) the adsorption of part of free As(III) by Fe-Al oxides on the bimetal surface at the initial stages of the process; (2) the oxidation of the majority of $\mathrm{As}(\mathrm{III})$ to $\mathrm{As}(\mathrm{V})$ by reactive oxygen species generated in the system, and the subsequent adsorption of $\mathrm{As}(\mathrm{V})$ by the Fe-Al (oxy)hydroxides on the bimetal surface; (3) the reduction of the adsorbed $\mathrm{As}(\mathrm{V})$ to $\mathrm{As}(\mathrm{III})$, and then to $\mathrm{As}(0)$ by $\mathrm{Fe}$ and $\mathrm{Al}$ (either directly or through the galvanic cell effect) in the anoxic inner layer of the bimetallic particles. Therefore, the observed discrepancy in the As uptake within $20 \mathrm{~min}$ of the process using different bimetal dosages corresponds most directly to the solution $\mathrm{pH}$ and the formation of the Fe-Al oxy-hydroxides on the bimetal (Figure 7a,b). For the AMD treated with 10 and $20 \mathrm{~g} / \mathrm{L}$ bimetal, the $\mathrm{pH}$ values reached more than 4 in $10 \mathrm{~min}$, while the same $\mathrm{pH}$ was recorded after $20 \mathrm{~min}$ for the experiment with $5 \mathrm{~g} / \mathrm{L}$ bimetal (Figure 4). Considering that under acidic and circumneutral $\mathrm{pH}$, the solubility, mobility, and toxicity of the As(III) is higher than $\mathrm{As}(\mathrm{V})$ species $[45,46]$, the Fe-Al bimetal seems to be an effective material for the As remediation from the contaminated water.

According to the redox potential (Table 2), $\mathrm{Cu}$ (II) and $\mathrm{Pb}(\mathrm{II})$ can be easily reduced to $\mathrm{Cu}^{0}$ and $\mathrm{Pb}^{0}$ by both $\mathrm{Fe}$ and $\mathrm{Al}$. Moreover, the reduction of $\mathrm{Cu}$ (II) to $\mathrm{Cu}$ (I) is also thermodynamically favored, resulting in the formation of insoluble $\mathrm{Cu}_{2} \mathrm{O}$ [42]. However, Igarashi, et al. (2020) [47] have shown that $\mathrm{Cu}$ precipitation at $\mathrm{pH}<6$ is unfavorable and its reduction is mostly attributed to co-precipitation with $\mathrm{Fe}$ and $\mathrm{Al}$ oxy-hydroxides. The metal contaminants with more negative redox potential than $\mathrm{Fe}$, including $\mathrm{Ni}, \mathrm{Zn}$, and $\mathrm{Mn}$, are hard to be reduced by Fe. The reduction by ZVAl and adsorption may be the predominant removal mechanism as the bimetal surface became more negatively charged with increasing $\mathrm{OH}^{-}$concentration, which enhanced the attraction between heavy metal ions and ZVI or ZVAl [28]. The higher removal of Zn, compared to Ni (Figure 6e,f), may be attributed to the adsorption by precipitated iron oxides on the bimetallic particles, which has been considered as a major Zn(II) removal mechanism by ZVI [48]. Moreover, due to the competitive effects, the uptake of $\mathrm{Ni}, \mathrm{Zn}$, and $\mathrm{Mn}$ by the bimetal may be hindered by $\mathrm{Hg}, \mathrm{As}, \mathrm{Cu}$, and $\mathrm{Pb}$ ions. In addition, as can be seen in Figure $7 \mathrm{c}-\mathrm{e}$, the $\mathrm{pH}$ increase in the system was not sufficient to drive $\mathrm{Mn}, \mathrm{Zn}$, and $\mathrm{Ni}$ precipitation as they exist as aqueous species under the experimental conditions. As can be seen in Figure $6 \mathrm{e}-\mathrm{g}$, concentrations of $\mathrm{Zn}, \mathrm{Ni}$, and $\mathrm{Mn}$ decreased over the first $10 \mathrm{~min}$ of the reaction before increasing again from 10 to $30 \mathrm{~min}$. The re-dissolution of these metal ions can be explained by the re-oxidation of deposited metals with the accumulated Fe(III) $\left(\left(\mathrm{Fe}^{3+} / \mathrm{Fe}^{2+}\right)=+0.77\right)$. In addition, the concentration of heavy metal ions such as $\mathrm{Zn}, \mathrm{Ni}$, and $\mathrm{Cu}$ do not seem to be affected by the high concentration of $\mathrm{Cl}^{-}$anion in the $\mathrm{pH}$ range of the experiments ( $\mathrm{pH}$ of 2-4) as it causes an increase in the metal's solubility [49-51]. However, in the case of $\mathrm{Hg}$, calomel $\left(\mathrm{Hg}_{2} \mathrm{Cl}_{2}\right)$ precipitation may contribute to its reduction from the solution [52,53].

Regarding the presence of nitrate ions in the system, it should be noted that nitrate has a higher electron affinity than metal ions in the process meaning it is more likely to gain electrons released from the bimetal in the competitive system. In the Fe-Al bimetallic system, both $\mathrm{Al}$ and $\mathrm{Fe}$ are able to reduce nitrate ion to nitrite $\left(\mathrm{NO}_{2}{ }^{-}\right)\left(\mathrm{E}^{\circ}=0.965 \mathrm{~V}\right)$, then ammonia $\left(\mathrm{NH}_{4}{ }^{+}\right)\left(\mathrm{E}^{\circ}=0.897 \mathrm{~V}\right)$ or nitrogen gas $[54,55]$. Further research should be 
undertaken to investigate the precise effect of $\mathrm{NO}_{3}{ }^{-}$and $\mathrm{Cl}^{-}$ions on heavy metal removal from $\mathrm{AMD}$ and on the bimetal performance.

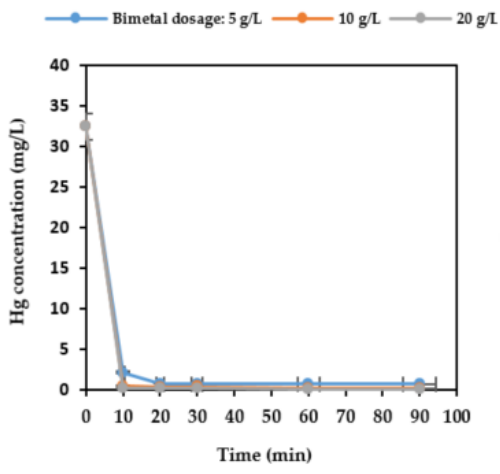

(a)

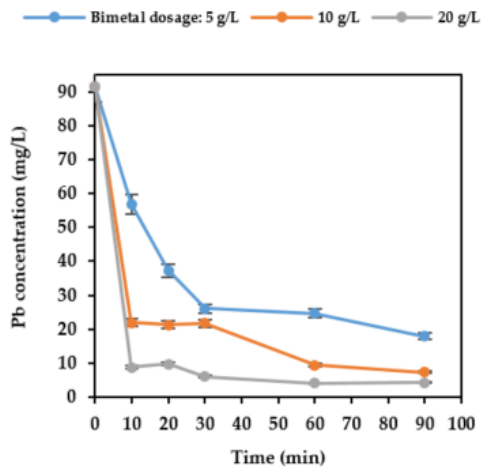

(d)

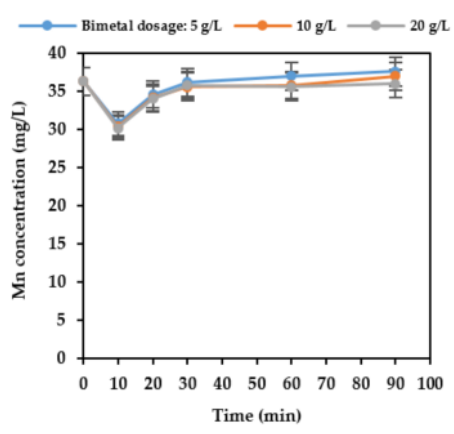

(g)

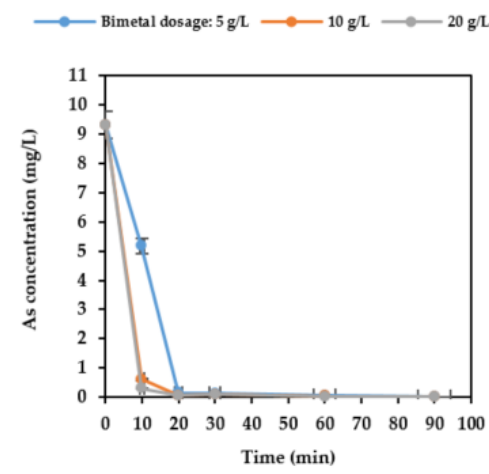

(b)

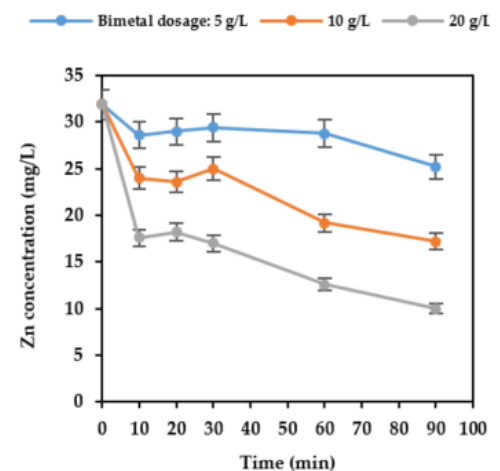

(e)

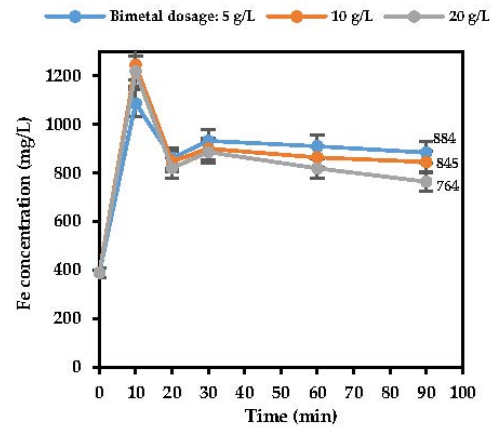

(h)

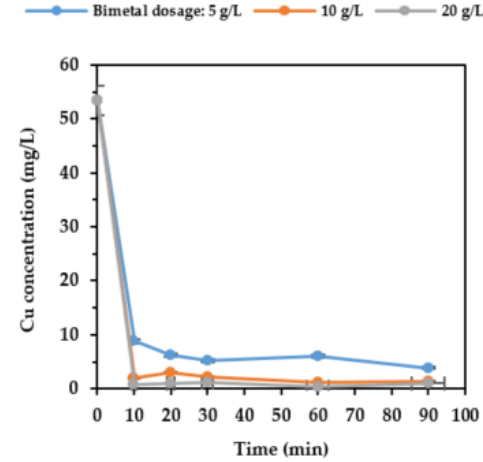

(c)

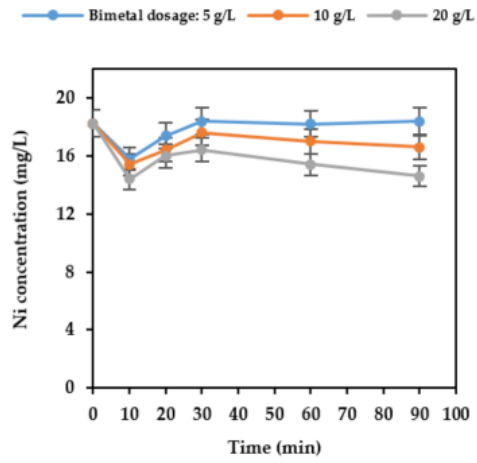

(f)

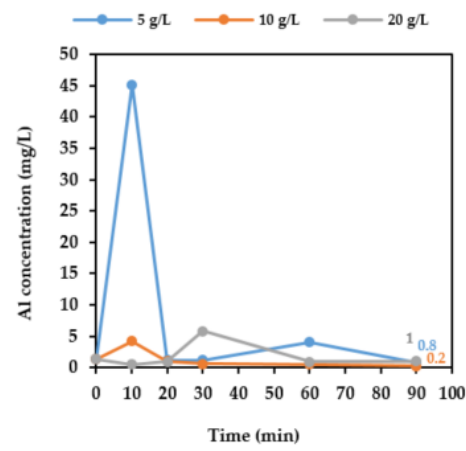

(i)

Figure 6. Variation of residual metal concentrations (a) As, (b) $\mathrm{Hg}$, (c) $\mathrm{Cu}$, (d) $\mathrm{Pb}$, (e) $\mathrm{Zn}$, (f) $\mathrm{Ni}$, (g) $\mathrm{Mn}$, (h) $\mathrm{Fe}$, and (i) $\mathrm{Al}$ over time at different bimetal dosage $(5,10$, and $20 \mathrm{~g} / \mathrm{L})$ and initial $\mathrm{pH}$ of 2.

The Fe corrosion (Equation (5)) led to a rise in its concentration in the solution within $10 \mathrm{~min}$ of the process (Figure $6 \mathrm{~h}$ ). However, it decreased after $10 \mathrm{~min}$, which may be attributed to the precipitation of Fe ions by increasing the $\mathrm{pH}$ (Figure 7a). The total Fe ions concentration after $90 \mathrm{~min}$ of the process using 5, 10, and $20 \mathrm{~g} / \mathrm{L}$ of the bimetal are 884,845 , and $764 \mathrm{mg} / \mathrm{L}$, respectively. The $\mathrm{pH}$ rise driven by increasing the bimetal dosage can be the main reason for the lower dissolved Fe ions concentrations. As can be seen in Figure $7 \mathrm{a}$ (the dashed rectangle) in the experimental Eh range $(0.5-0.21 \mathrm{~V})$ and $\mathrm{pH}>4$, 
Fe may precipitate as Schwertmannite or Magnetite. Moreover, depending on the $\mathrm{Fe}^{2+}$, $\mathrm{Fe}^{3+}$, and $\mathrm{Cl}^{-}$concentrations, $\mathrm{pH}$, and temperature of the reaction mixture, chloride ions may incorporate into the iron (oxy)hydroxide structure to form akaganetite [56,57], which has shown desirable sorption properties for PTE, such as As and Zn [58,59]. So, further research is needed to better understand the possibility of akaganetite formation under the experimental conditions of this study.
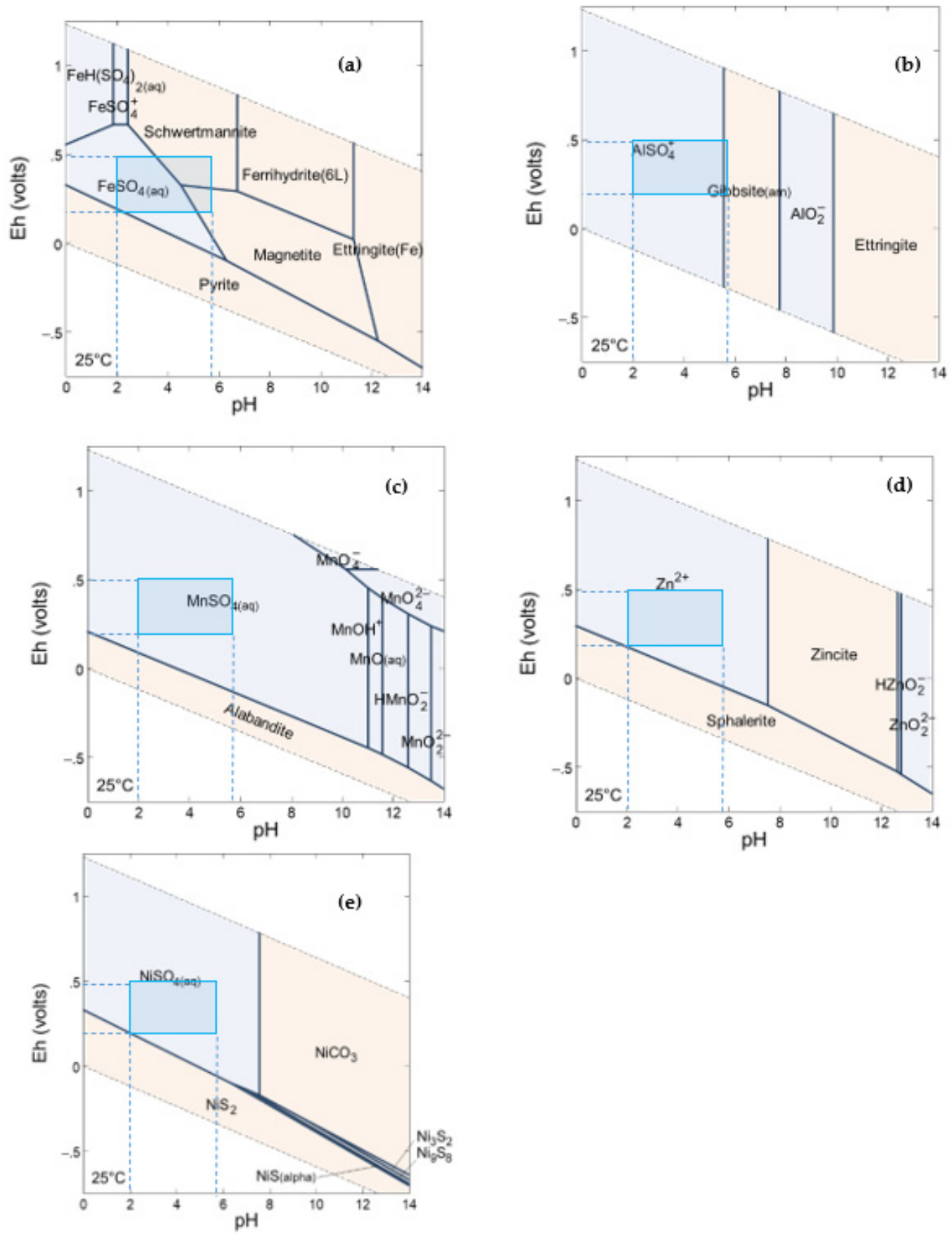

Figure 7. Eh- $\mathrm{pH}$ predominance diagram of (a) $\mathrm{Fe}^{3+}$ (activity $\left.=10^{-2.65}\right),(\mathbf{b}) \mathrm{Al}^{3+}\left(\right.$ activity $\left.=10^{-4.53}\right),(\mathbf{c}) \mathrm{Mn}^{2+}($ activity $\left.=10^{-3.99}\right)$, (d) $\mathrm{Zn}^{2+}\left(\right.$ activity $\left.=10^{-3.9}\right)$, and $(\mathbf{e})$ of $\mathrm{Ni}^{2+}\left(\right.$ activity $\left.=10^{-3.7}\right)$ at $25^{\circ} \mathrm{C}, 1.013$ bars and activities of $\mathrm{SO}_{4}{ }^{2-}, \mathrm{Na}^{+}$ and $\mathrm{Ca}^{2+}$ equal to $10^{-1.6}, 10^{-0.57}$ and $10^{-2.4}$, respectively. Carbonate was modelled in the system by equilibrating it with the average $\mathrm{CO}_{2}$ in air (Fugacity $=10^{-3.5}$ ). The dashed rectangle refers to experimental conditions in this study. 
Considering that the maximum recommended level of Fe in drinking water by the World Health Organization (WHO) is $2 \mathrm{mg} / \mathrm{L}$ [25], the release of Fe ions from the bimetal after the reaction with AMD is significant. However, Fe is less harmful compared to toxic heavy metals content in AMD and can be removed from the solution by a secondary neutralization process and converted to usable iron oxides as a raw material in pigments, ceramics, etc. [37]. The $\mathrm{Al}^{3+}$ concentrations in the final solutions are negligible, except for the experiment with $5 \mathrm{~g} / \mathrm{L}$ of the bimetal within $10 \mathrm{~min}$ of the process in which the total dissolved $\mathrm{AL}^{3+}$ was $45 \mathrm{mg} / \mathrm{L}$ (Figure 6i). It is attributed to the solution $\mathrm{pH}$, which is less than 3 , and $\mathrm{Al}^{3+}$ is the predominant species (Figure $7 \mathrm{~b}$ ). In addition, the $\mathrm{Al}^{3+}$ concentration in the experiment using $10 \mathrm{~g} / \mathrm{L}$ of the bimetal and the reaction time of 90 min meet the established limit in drinking water by WHO $(0.2 \mathrm{mg} / \mathrm{L})[25]$.

\section{Conclusions}

In this investigation, the synthesized Fe-Al bimetallic material has demonstrated high efficiency for a rapid removal of potentially toxic elements from the combined AMD-waste solutions resulting from refractory gold production. Owing to a greater tendency for electrons released from the bimetal, higher removal rate was obtained for $\mathrm{Hg}, \mathrm{As}, \mathrm{Cu}$, and $\mathrm{Pb}$ than the $\mathrm{Ni}, \mathrm{Zn}$, and $\mathrm{Mn}$. Experiments with $20 \mathrm{~g} / \mathrm{L}$ of the bimetal resulted in significant removal of $\mathrm{Hg}(99.74 \%)$, As (99.80\%), $\mathrm{Cu}(98.20 \%)$, and $\mathrm{Pb}(95.50 \%)$ in $90 \mathrm{~min}$, while it dropped to $69.50 \%$ removal for $\mathrm{Zn}, 22.34 \%$ for $\mathrm{Ni}$, and $<5 \%$ for $\mathrm{Mn}$. Therefore, the electrochemical reduction of PTE by the bimetal seems to be the major contributing mechanism. The findings of this study also indicate that the higher bimetal dosages result in the greater heavy metal uptake from the solution. Moreover, the corrosion of Fe and $\mathrm{Al}$ in the bimetallic system and consequently the release of $\mathrm{Fe}(\mathrm{III}), \mathrm{Al}(\mathrm{III})$, and $\mathrm{OH}^{-}$ions into the solution led to the formation of Fe-Al (oxy)hydroxides which could sequester PTE, such as $\mathrm{Hg}$ and $\mathrm{Zn}$, via adsorption. In addition, with respect to electrode potential of metal species, $\mathrm{Fe}(\mathrm{III})$ ions engaged in the re-oxidation of deposited $\mathrm{Zn}$, and more significantly $\mathrm{Mn}$ and $\mathrm{Ni}$, led to an increase in their concentrations after $10 \mathrm{~min}$. The increase in the initial $\mathrm{pH}$ of 2 to more than 5 in 90 min using Fe-Al bimetallic particles is promising in AMD remediation as it can reduce the amount of alkaline reagents. Nearly no Al ions were detected in the solutions at higher bimetal concentrations. Although the Fe release from the bimetal was high, it can be precipitated and converted to a valuable by-product such as iron pigments. However, more research on this topic needs to be undertaken to identify the influencing parameters, characterize and analyze the surface chemistry of bimetallic particles after reaction with PTE and measure the elemental composition, and chemical and electronic state of the elements on the bimetal. Chloride ions in the studied system may affect the process by akaganeite formation and changing the stability of PTE. Moreover, the higher electrode potential of nitrate compared to $\mathrm{Fe}, \mathrm{Al}$, and other metals in the process, could mean it has a higher tendency to gain electrons and get reduced. However, further studies regarding the precise effect of $\mathrm{Cl}^{-}$and $\mathrm{NO}_{3}{ }^{-}$on PTE removal and bimetal performance is strongly recommended. The reversibility of the process and reusability of the bimetal also warrant additional investigation.

Author Contributions: Conceptualization, R.D.A., C.B.T., E.A.; methodology, E.A. and R.D.A.; validation and analysis, E.A., Z.W., R.D.A. and Z.Q.; writing-original draft preparation, E.A. and Z.W.; writing-review and editing, R.D.A., B.T., C.B.T. and E.A.; supervision, R.D.A. and B.T.; All authors have read and agreed to the published version of the manuscript.

Funding: This research received no external funding.

Data Availability Statement: Data sharing is not applicable to this article.

Acknowledgments: Curtin University's Strategic Scholarship is gratefully acknowledged for the PhD scholarship granted to Elham Aghaei.

Conflicts of Interest: The authors declare no conflict of interest. 


\section{References}

1. Park, I.; Tabelin, C.B.; Jeon, S.; Li, X.; Seno, K.; Ito, M.; Hiroyoshi, N. A review of recent strategies for acid mine drainage prevention and mine tailings recycling. Chemosphere 2019, 219, 588-606. [CrossRef] [PubMed]

2. Moodley, I.; Sheridan, C.M.; Kappelmeyer, U.; Akcil, A. Environmentally sustainable acid mine drainage remediation: Research developments with a focus on waste/by-products. Miner. Eng. 2018, 126, 207-220. [CrossRef]

3. Wilkin, R.T.; McNeil, M.S. Laboratory evaluation of zero-valent iron to treat water impacted by acid mine drainage. Chemosphere 2003, 53, 715-725. [CrossRef]

4. Wills, B.A.; Finch, J.A. Chapter 16-Tailings Disposal. In Wills' Mineral Processing Technology (Eighth Edition); Wills, B.A., Finch, J.A., Eds.; Butterworth-Heinemann: Boston, FL, USA, 2016; pp. 439-448. [CrossRef]

5. Kefeni, K.K.; Msagati, T.A.M.; Mamba, B.B. Acid mine drainage: Prevention, treatment options, and resource recovery: A review. J. Clean. Prod. 2017, 151, 475-493. [CrossRef]

6. Naidu, G.; Ryu, S.; Thiruvenkatachari, R.; Choi, Y.; Jeong, S.; Vigneswaran, S. A critical review on remediation, reuse, and resource recovery from acid mine drainage. Environ. Pollut. 2019, 247, 1110-1124. [CrossRef] [PubMed]

7. Dold, B. Evolution of Acid Mine Drainage Formation in Sulphidic Mine Tailings. Minerals 2014, 4, 621-641. [CrossRef]

8. Diao, Z.; Shi, T.; Wang, S.; Huang, X.; Zhang, T.; Tang, Y.; Zhang, X.; Qiu, R. Silane-based coatings on the pyrite for remediation of acid mine drainage. Water Res. 2013, 47, 4391-4402. [CrossRef] [PubMed]

9. Shu, X.; Dang, Z.; Zhang, Q.; Yi, X.; Lu, G.; Guo, C.; Yang, C. Passivation of metal-sulfide tailings by covalent coating. Miner. Eng. 2013, 42, 36-42. [CrossRef]

10. Alakangas, L.; Andersson, E.; Mueller, S. Neutralization/prevention of acid rock drainage using mixtures of alkaline by-products and sulfidic mine wastes. Environ. Sci. Pollut. Res. 2013, 20, 7907-7916. [CrossRef]

11. Nason, P.; Johnson, R.H.; Neuschütz, C.; Alakangas, L.; Öhlander, B. Alternative waste residue materials for passive in situ prevention of sulfide-mine tailings oxidation: A field evaluation. J. Hazard. Mater. 2014, 267, 245-254. [CrossRef]

12. Jin, S.; Fallgren, P.H.; Morris, J.M.; Cooper, J.S. Source Treatment of Acid Mine Drainage at a Backfilled Coal Mine Using Remote Sensing and Biogeochemistry. Water Air Soil Pollut. 2008, 188, 205-212. [CrossRef]

13. Li, X.; Hiroyoshi, N.; Tabelin, C.B.; Naruwa, K.; Harada, C.; Ito, M. Suppressive effects of ferric-catecholate complexes on pyrite oxidation. Chemosphere 2019, 214, 70-78. [CrossRef]

14. Jones, S.N.; Cetin, B. Evaluation of waste materials for acid mine drainage remediation. Fuel 2017, 188, 294-309. [CrossRef]

15. Bortnikova, S.; Gaskova, O.; Yurkevich, N.; Saeva, O.; Abrosimova, N. Chemical Treatment of Highly Toxic Acid Mine Drainage at A Gold Mining Site in Southwestern Siberia, Russia. Minerals 2020, 10, 867. [CrossRef]

16. Pat-Espadas, A.M.; Loredo Portales, R.; Amabilis-Sosa, L.E.; Gómez, G.; Vidal, G. Review of Constructed Wetlands for Acid Mine Drainage Treatment. Water 2018, 10, 1685. [CrossRef]

17. Fytas, K. Use of permeable reactive barriers to treat acid mine effluents. Int. J. Min. Reclam. Environ. 2010, 24, 206-215. [CrossRef]

18. Gibert, O.; Rötting, T.; Cortina, J.L.; de Pablo, J.; Ayora, C.; Carrera, J.; Bolzicco, J. In-situ remediation of acid mine drainage using a permeable reactive barrier in Aznalcóllar (Sw Spain). J. Hazard. Mater. 2011, 191, 287-295. [CrossRef] [PubMed]

19. Kaksonen, A.H.; Puhakka, J.A. Sulfate Reduction Based Bioprocesses for the Treatment of Acid Mine Drainage and the Recovery of Metals. Eng. Life Sci. 2007, 7, 541-564. [CrossRef]

20. Gitari, M.W.; Petrik, L.F.; Etchebers, O.; Key, D.L.; Iwuoha, E.; Okujeni, C. Treatment of acid mine drainage with fly ash: Removal of major contaminants and trace elements. J. Environ. Sci. Health Part A Toxic/Hazard. Subst. Environ. Eng. 2006, 41, $1729-1747$. [CrossRef]

21. Wu, Y.; Guan, C.-Y.; Griswold, N.; Hou, L.-Y.; Fang, X.; Hu, A.; Hu, Z.-Q.; Yu, C.-P. Zero-valent iron-based technologies for removal of heavy metal(loid)s and organic pollutants from the aquatic environment: Recent advances and perspectives. J. Clean. Prod. 2020, 277, 123478. [CrossRef]

22. Obiri-Nyarko, F.; Grajales-Mesa, S.J.; Malina, G. An overview of permeable reactive barriers for in situ sustainable groundwater remediation. Chemosphere 2014, 111, 243-259. [CrossRef] [PubMed]

23. Nidheesh, P.V.; Khatri, J.; Anantha Singh, T.S.; Gandhimathi, R.; Ramesh, S.T. Review of zero-valent aluminium based water and wastewater treatment methods. Chemosphere 2018, 200, 621-631. [CrossRef] [PubMed]

24. Chen, L.-H.; Huang, C.-C.; Lien, H.-L. Bimetallic iron-aluminum particles for dechlorination of carbon tetrachloride. Chemosphere 2008, 73, 692-697. [CrossRef] [PubMed]

25. Fu, F.; Cheng, Z.; Dionysiou, D.D.; Tang, B. Fe/Al bimetallic particles for the fast and highly efficient removal of Cr(VI) over a wide $\mathrm{pH}$ range: Performance and mechanism. J. Hazard. Mater. 2015, 298, 261-269. [CrossRef]

26. Cheng, Z.; Fu, F.; Dionysiou, D.D.; Tang, B. Adsorption, oxidation, and reduction behavior of arsenic in the removal of aqueous As(III) by mesoporous Fe/Al bimetallic particles. Water Res. 2016, 96, 22-31. [CrossRef]

27. Xiang, S.; Cheng, W.; Nie, X.; Ding, C.; Yi, F.; Asiri, A.M.; Marwani, H.M. Zero-valent iron-aluminum for the fast and effective U(VI) removal. J. Taiwan Inst. Chem. Eng. 2018, 85, 186-192. [CrossRef]

28. Han, W.; Fu, F.; Cheng, Z.; Tang, B.; Wu, S. Studies on the optimum conditions using acid-washed zero-valent iron/aluminum mixtures in permeable reactive barriers for the removal of different heavy metal ions from wastewater. J. Hazard. Mater. 2016, 302, 437-446. [CrossRef]

29. Iakovleva, E.; Mäkilä, E.; Salonen, J.; Sitarz, M.; Wang, S.; Sillanpää, M. Acid mine drainage (AMD) treatment: Neutralization and toxic elements removal with unmodified and modified limestone. Ecol. Eng. 2015, 81, 30-40. [CrossRef] 
30. Marsden, J.O.; House, C.I. Chemistry of Gold Extraction, 2nd ed.; SME: Littleton, CO, USA, 2009.

31. Deschenes, G.; Lastra, R.; Brown, J.R.; Jin, S.; May, O.; Ghali, E. Effect of lead nitrate on cyanidation of gold ores: Progress on the study of the mechanisms. Miner. Eng. 2000, 13, 1263-1279. [CrossRef]

32. Deschênes, G.; McMullen, J.; Ellis, S.; Fulton, M.; Atkin, A. Investigation on the cyanide leaching optimization for the treatment of KCGM gold flotation concentrate-phase 1. Miner. Eng. 2005, 18, 832-838. [CrossRef]

33. Ali, R.; Turner, J. A Study of the Suitability of Saline Surface Water for Recharging the Hypersaline Palaeochannel Aquifers of the Eastern Goldfields of Western Australia. Mine Water Environ. 2004, 23, 110-118. [CrossRef]

34. Muir, D.M. Gold Processing with Saline Water; The Australasian Institute of Mining and Metallurgy: Carlton, Australia, 1994.

35. Bethke, C.M.; Yeakel, S. The Geochemist's Workbench-A User's Guide to GSS, Rxn, Act2, Tact, Spec8, React, Gtplot, X1t, X2t, and Xtplot; Aqueous Solutions LLC: Urbana, IL, USA, 2011.

36. Blanc, P.; Lassin, A.; Piantone, P.; Azaroual, M.; Jacquemet, N.; Fabbri, A.; Gaucher, E.C. Thermoddem: A geochemical database focused on low temperature water/rock interactions and waste materials. Appl. Geochem. 2012, 27, 2107-2116. [CrossRef]

37. Simate, G.S.; Ndlovu, S. Acid mine drainage: Challenges and opportunities. J. Environ. Chem. Eng. 2014, 2, 1785-1803. [CrossRef]

38. Lien, H.-L.; Yu, C.-H.; Kamali, S.; Sahu, R.S. Bimetallic Fe/Al system: An all-in-one solid-phase Fenton reagent for generation of hydroxyl radicals under oxic conditions. Sci. Total Environ. 2019, 673, 480-488. [CrossRef] [PubMed]

39. Wu, S.; Yang, S.; Liu, S.; Zhang, Y.; Ren, T.; Zhang, Y. Enhanced reactivity of zero-valent aluminum with ball milling for phenol oxidative degradation. J. Colloid Interface Sci. 2020, 560, 260-272. [CrossRef]

40. Bokare, A.D.; Choi, W. Zero-valent aluminum for oxidative degradation of aqueous organic pollutants. Environ. Sci. Technol. 2009, 43, 7130-7135. [CrossRef]

41. Yang, S.; Zheng, D.; Ren, T.; Zhang, Y.; Xin, J. Zero-valent aluminum for reductive removal of aqueous pollutants over a wide $\mathrm{pH}$ range: Performance and mechanism especially at near-neutral pH. Water Res. 2017, 123, 704-714. [CrossRef] [PubMed]

42. O'Carroll, D.; Sleep, B.; Krol, M.; Boparai, H.; Kocur, C. Nanoscale zero valent iron and bimetallic particles for contaminated site remediation. Adv. Water Resour. 2013, 51, 104-122. [CrossRef]

43. Vernon, J.D.; Bonzongo, J.-C.J. Volatilization and sorption of dissolved mercury by metallic iron of different particle sizes: Implications for treatment of mercury contaminated water effluents. J. Hazard. Mater. 2014, 276, 408-414. [CrossRef] [PubMed]

44. Meng, C.; Mao, Q.; Luo, L.; Zhang, J.; Wei, J.; Yang, Y.; Tan, M.; Peng, Q.; Tang, L.; Zhou, Y. Performance and mechanism of As(III) removal from water using Fe-Al bimetallic material. Sep. Purif. Technol. 2018, 191, 314-321. [CrossRef]

45. Liu, F.; Yang, W.; Li, W.; Zhao, G.-C. Simultaneous Oxidation and Sequestration of Arsenic(III) from Aqueous Solution by Copper Aluminate with Peroxymonosulfate: A Fast and Efficient Heterogeneous Process. ACS Omega 2021, 6, 1477-1487. [CrossRef] [PubMed]

46. Tabelin, C.B.; Igarashi, T.; Villacorte-Tabelin, M.; Park, I.; Opiso, E.M.; Ito, M.; Hiroyoshi, N. Arsenic, selenium, boron, lead, cadmium, copper, and zinc in naturally contaminated rocks: A review of their sources, modes of enrichment, mechanisms of release, and mitigation strategies. Sci. Total Environ. 2018, 645, 1522-1553. [CrossRef]

47. Igarashi, T.; Herrera, P.S.; Uchiyama, H.; Miyamae, H.; Iyatomi, N.; Hashimoto, K.; Tabelin, C.B. The two-step neutralization ferrite-formation process for sustainable acid mine drainage treatment: Removal of copper, zinc and arsenic, and the influence of coexisting ions on ferritization. Sci. Total Environ. 2020, 715, 136877. [CrossRef]

48. Rangsivek, R.; Jekel, M.R. Removal of dissolved metals by zero-valent iron (ZVI): Kinetics, equilibria, processes and implications for stormwater runoff treatment. Water Res. 2005, 39, 4153-4163. [CrossRef]

49. Beverskog, B.; Puigdomenech, I. Pourbaix Diagrams for the System Copper-Chlorine at 5-100 ${ }^{\circ}$ C; Swedish Nuclear Power Inspectorate: Stockholm, Sweden, 1998; p. 56.

50. He, D.; Zeng, L.; Zhang, G.; Guan, W.; Cao, Z.; Li, Q.; Wu, S. Extraction behavior and mechanism of nickel in chloride solution using a cleaner extractant. J. Clean. Prod. 2020, 242, 118517. [CrossRef]

51. Stec, M.; Jagustyn, B.; Słowik, K.; Ściążko, M.; Iluk, T. Influence of High Chloride Concentration on pH Control in Hydroxide Precipitation of Heavy Metals. J. Sustain. Metall. 2020, 6, 239-249. [CrossRef]

52. Grassi, S.; Netti, R. Sea water intrusion and mercury pollution of some coastal aquifers in the province of Grosseto (Southern Tuscany-Italy). J. Hydrol. 2000, 237, 198-211. [CrossRef]

53. Spyropoulou, A.; Lazarou, Y.G.; Laspidou, C. Mercury Speciation in the Water Distribution System of Skiathos Island, Greece. Proceedings 2018, 2, 668. [CrossRef]

54. Liu, Y.; Wang, J. Reduction of nitrate by zero valent iron (ZVI)-based materials: A review. Sci. Total Environ. 2019, 671, 388-403. [CrossRef]

55. Esfahani, A.R.; Datta, T. Nitrate removal from water using zero-valent aluminium. Water Environ. J. 2020, 34, 25-36. [CrossRef]

56. Scheck, J.; Lemke, T.; Gebauer, D. The Role of Chloride Ions during the Formation of Akaganéite Revisited. Minerals 2015, 5, 778-787. [CrossRef]

57. Rémazeilles, C.; Refait, P. On the formation of $\beta-\mathrm{FeOOH}$ (akaganéite) in chloride-containing environments. Corros. Sci. 2007, 49, 844-857. [CrossRef]

58. Zhao, J.; Lin, W.; Chang, Q.; Li, W.; Lai, Y. Adsorptive characteristics of akaganeite and its environmental applications: A review. Environ. Technol. Rev. 2012, 1, 114-126. [CrossRef]

59. Deliyanni, E.A.; Bakoyannakis, D.N.; Zouboulis, A.I.; Peleka, E. Removal of Arsenic and Cadmium by Akaganeite Fixed-Beds. Sep. Sci. Technol. 2003, 38, 3967-3981. [CrossRef] 